\title{
Melt Processed Multiphase Ceramic Waste Forms for Nuclear Waste Immobilization
}

\author{
Jake Amoroso ${ }^{\mathrm{a},}{ }^{*}$, James C. Marra ${ }^{\mathrm{a}}$, Ming Tang ${ }^{\mathrm{b}}$, Ye Lin ${ }^{\mathrm{c}}$, Fanglin Chen ${ }^{\mathrm{c}}$, Dong Su ${ }^{\mathrm{d}}$, Kyle S. \\ Brinkman $^{\mathrm{e}}$ \\ ${ }^{a}$ Savannah River National Laboratory, Aiken, SC 29808, USA \\ ${ }^{\mathrm{b}}$ Los Alamos National Laboratory, Los Alamos, NM 87545, USA \\ ${ }^{\mathrm{c}}$ University of South Carolina, Columbia, SC 29208, USA \\ ${ }^{\mathrm{d}}$ Brookhaven National Laboratory, Upton, NY 11973, USA \\ ${ }^{\mathrm{e}}$ Clemson University, Clemson, SC 29634, USA
}

\begin{abstract}
Ceramic waste forms are promising hosts for nuclear waste immobilization as they have the potential for increased durability and waste loading compared with conventional borosilicate glass waste forms. Ceramics are generally processed using hot pressing, spark plasma sintering, and conventional solid-state reaction, however such methods can be prohibitively expensive or impractical at production scales. Recently, melt processing has been investigated as an alternative to solid-state sintering methods. Given that melter technology is currently in use for High Level Waste (HLW) vitrification in several countries, the technology readiness of melt processing appears to be advantageous over sintering methods. This work reports the development of candidate multi-phase ceramic compositions processed from a melt. $\mathrm{Cr}$ additions, developed to promote the formation and stability of a Cs containing hollandite phase were successfully incorporated into melt processed multi-phase ceramics. Control of the
\end{abstract}


reduction-oxidation (Redox) conditions suppressed undesirable Cs-Mo containing phases, and additions of $\mathrm{Al}$ and $\mathrm{Fe}$ reduced the melting temperature.

Keywords: Ceramic; Nuclear; Durability, Melt; Waste; Synroc

[*] Corresponding Author: (Tel.) 803-819-4727; (E-mail): jake.amoroso@ srs.gov

\subsection{Introduction}

Waste treatment technologies are an integral component to The United States Department of Energy (DOE) Fuel Cycle Research and Development (FCR\&D) program. Successful waste treatment and storage are necessary to support next-generation nuclear energy development. A single waste form that can host all the waste elements in the projected aqueous reprocessing high-level waste (HLW) is most desirable [1].

The traditional method for HLW immobilization is to form borosilicate glass by a vitrification process, a practice currently used for defense and commercial waste [2]. Durable ceramic waste forms that incorporate a wide range of radionuclides have the potential to broaden the available disposal options and to lower the storage and disposal costs associated with advanced fuel cycles. Ceramic waste forms are tailored (engineered) to incorporate waste components as part of their crystal structure based on knowledge from naturally found minerals containing radioactive and non-radioactive species similar to the radionuclides of concern in wastes from fuel reprocessing. The ability to tailor ceramics to mimic naturally occurring crystals substantiates the long term stability of such crystals (ceramics) over geologic timescales of interest for nuclear waste immobilization [3].

Multiphase ceramics targeting an assemblage of titanate-based phases have been successfully demonstrated to incorporate various radioactive waste elements into a number of crystalline 
phases. Most notable are the synthetic rock (SYNROC) family of minerals developed in the 1980s that have been primarily produced by hot-pressing $[4,5]$. Melt processing of waste forms is considered advantageous over the conventional solid-state synthesis methods given that melters are currently in use for HLW vitrification in several countries, greatly facilitating the technology readiness of ceramic waste forms, and melter technology can reduce the potential for airborne contamination during pretreatment as compared to processes involving extensive powder handling operations.

There have been several comparative studies of crystalline ceramic waste forms produced by hot pressing and inductive melting [6,7]. These prior studies have indicated that the specimens fabricated by melt processing and solid state sintering exhibited similar mineral compositions, with the exception of a water-soluble molybdate phase observed in melt processing Mo containing waste streams in air. Under oxidizing processing conditions, attempts to make single phase hollandite (the host phase for Cs) ceramics are difficult and more often results in secondary metastable Cs containing phases [8]. It has been demonstrated that these secondary phases can be suppressed by controlling the starting compositions and the $\mathrm{Ti}^{3+} / \mathrm{Ti}^{4+}$ during processing. Metal powder (Ti) additions to the batch material or hot pressing in graphite have been shown to be effective methods for controlling the redox conditions during sintering $[9,10]$.

A major objective of the present work was aimed at varying the composition and processing conditions in order to mitigate Cs-Mo molybdate phase formation. In addition, there was particular interest regarding the characteristics of phase formation and elemental partitioning in melt processed ceramic composites. The intent of this work is to demonstrate the feasibility of melt processing technology to produce multiphase waste forms with phase composition comparable to conventional methods. 


\subsection{Composition Development}

\subsection{Projected Waste Composition}

The waste composition that formed the basis for the development and testing is given in Table 1. Noble metals, minor actinides and Tc were removed for cost and handling reasons. The $\mathrm{MoO}_{3}$ targeted in this work was based on one possible reprocessing flowsheet, but other variants exist and more will be developed based in part on waste form studies such as this. Because this work incorporated varying Redox conditions and previous results indicated large concentrations of $\mathrm{MoO}_{3}$ inhibited desired phase formation under oxidizing conditions, the $\mathrm{MoO}_{3}$ concentration was targeted at 3 wt. \% to simplify comparison among samples.

\subsection{Single Phase Hollandite}

Hollandite-type structures are a promising crystalline host for $\mathrm{Cs}$, one of the more problematic fission products to immobilize. Melt processed single phase Cs-containing hollandite ceramics with $\mathrm{Cr}$ additions of the form $\mathrm{Ba}_{1.0} \mathrm{Cs}_{0.3} \mathrm{~A}_{2.3} \mathrm{Ti}_{5.7} \mathrm{O}_{16}(\mathrm{~A}=\mathrm{Cr}, \mathrm{Fe}, \mathrm{Al})$ were developed precursory to this work. Durability studies indicated that $\mathrm{Cr}$ additions increased Cs retention and suppressed secondary phase formation compared to Fe-hollandite analogs. Processing in various redox conditions affected the phase purity of Fe-containing hollandites whereas had negligible effect on the resulting phase purity in the Cr-containing hollandites. X-ray absorption spectroscopy confirmed the relative stability of $\mathrm{Cr}^{+3}$ as compared to $\mathrm{Fe}^{+3}$ in various redox conditions. It is speculated that $\mathrm{Cr}$ helps to stabilize the hollandite phase during forming which in turn promotes Cs incorporation into the hollandite [9]. Hollandite compositions with $\mathrm{Cr}$ additions are considered a promising phase for Cs-immobilization and served as the basis for multi-phase ceramic waste form compositions presented in this work. 


\subsection{Calculation of Multi Phase Waste Form Compositions}

In this work, optimized single phase hollandite compositions based on $\mathrm{Cr}$ and $\mathrm{Cr} / \mathrm{Al} / \mathrm{Fe}$ additions were incorporated into multiphase ceramics targeting hollandite, perovskite/pyrochlore and zirconolite phase assemblages. The phase assemblages were designed based on combinations of the waste and additives (the primary additive being $\mathrm{TiO}_{2}$ ) to target the desired phases (i.e. hollandite, perovskite/pyrochlore and zirconolite) upon melting. Literature data and valence state were used to predict which phases each element would partition to. Specifically, elements with $\mathrm{a}+3$ or +2 valance with titania form pyrochlore and perovskite type structures resulting in $\left(\mathrm{A}^{+2}\right) \mathrm{TiO}_{3}$ and $\left(\mathrm{A}^{+3}\right)_{2} \mathrm{Ti}_{2} \mathrm{O}_{7}$ type phases $[11,12]$. Zirconium has been demonstrated to partition to a $\mathrm{CaZrTi}_{2} \mathrm{O}_{7}$ zirconolite phase [13]. The $\mathrm{Cs}$ and $\mathrm{Rb}$ elements are known to partition to a hollandite structure based on the general formula $\mathrm{Ba}_{\mathrm{x}} \mathrm{Cs}_{\mathrm{y}} \mathrm{M}_{\mathrm{z}} \mathrm{Ti}^{+4}{ }_{8-\mathrm{z}} \mathrm{O}_{16}$ where $\mathrm{M}=$ metal cation and $\mathrm{z}=2 \mathrm{x}+\mathrm{y}$ for trivalent cations and $\mathrm{z}=\mathrm{x}+\mathrm{y} / 2$ for divalent cations for charge compensation $[8$, $14,15]$.

The waste and additive calculations were based on combining oxide and carbonate powders, as described in Section 3.1.1. Table 2 summarizes the two multiphase compositions (based on $\mathrm{Cr}$ and $\mathrm{Cr} / \mathrm{Al} / \mathrm{Fe}$ additions) that were prepared for this work, each with $\sim 25$ weight $\%$ waste loading and varying additive concentrations. Cr-MP denotes a multiphase assemblage targeting the $\mathrm{Cr}$ hollandite analog and CAF-MP denotes a multiphase assemblage targeting the $\mathrm{Cr} / \mathrm{Al} / \mathrm{Fe}$ hollandite analog. The batch oxide components in wt. \% percent and associated target phase are listed in Table 3 for both multiphase compositions. 


\subsection{Experimental}

\subsection{Fabrication and Melt Processing}

\subsubsection{Batch Preparation}

For each batch, stoiciometric amounts of reagent-grade oxide and carbonate powders $(99.5 \%$ purity to make $100 \mathrm{~g}$ of final material were combined in a $500 \mathrm{ml}$ plastic bottle with zirconia milling media, filled $2 / 3$ full with deionized water, and agitated in a tumbler mixer for 1 hour. Subsequently, the slurry was poured into a pan along with additional rinse water used to collect any batch material remaining on the milling media and bottles. The pan was transferred to an oven where the slurry was dried for several days at $90^{\circ} \mathrm{C}$. The dried material was bagged and used as feed stock for synthesis experiments.

\subsubsection{Melt Processing}

Approximately $20 \mathrm{~g}$ samples feed stock was placed loosely into a covered alumina crucible. Samples were heated at approximately $15 \mathrm{~K} / \mathrm{min}$, held at $1500^{\circ} \mathrm{C}$ for 20 minutes, and furnace cooled (powered off furnace). Estimated cooling rates were initially $60 \mathrm{~K} / \mathrm{min}$ but had reduced to $15 \mathrm{~K} / \mathrm{min}$ by approximately $1200^{\circ} \mathrm{C}$. The samples were heated in air and in $1 \% \mathrm{H}_{2}(99 \% \mathrm{Ar})$ reducing atmosphere. Ti metal and $\mathrm{TiO}_{2}$ additions were made to some batches prior to synthesis. For those samples, mixtures of $2.0 \mathrm{wt} . \%$ Ti metal and $7.0 \mathrm{wt} . \% \mathrm{TiO}_{2}$ were weighed in an inert glove box and manually mixed into each batch prior to melting. Table 4 summarizes the experimental matrix including $\mathrm{TiO}_{2}$ additions and processing conditions. 


\subsection{Characterization}

\subsubsection{Phase Identification and Microstructure}

Samples were characterized with x-ray diffraction (XRD, D8 Advance, Bruker AXS Inc., Madison, WI) to identify the resulting phase(s). Portions of each sample were initially ground in an automatic Spex mill for 4 minutes. Subsequently, the powders were hand ground with an agate mortar and pestle in alcohol and mounted to a glass slide using a collidion/Amyl Acetate solution. The XRD patterns were collected at a $0.02^{\circ}$ stepped scan from $5-70^{\circ} 2 \theta$ at a scan rate of $1 \mathrm{sec} / \mathrm{step}$.

Scanning Electron Microscopy (SEM) and Energy Dispersive Spectroscopy (EDS) measurements were performed on all samples at the Savannah River National Laboratory (SRNL) with a Hitachi TM3000 SEM. Microstructure and chemical composition of selected samples were investigated on a Hitachi HD2700C Scanning Tunneling Electron Microscope (STEM) instrument equipped with EDS. STEM samples were firstly sectioned with a diamond saw to $0.5 \mathrm{~mm}$ thickness. Subsequently, circular discs were cut from each sample using an ultrasonic disk cutter, and smooth disc faces were obtained after polishing using 60 to 1000 grit grinding paper. A conventional dimpling process was performed using a Gatan dimpler 626 and the final sample thickness reduction to less than $10 \mathrm{~nm}$ was accomplished by ion milling using a Fischione Model 1010 instrument. STEM-EDS mapping of Cs, Ba, Mo, Zr, Cr, Al, Fe, Nd, Ca, $\mathrm{La}, \mathrm{Ce}$, and Ti was performed.

\subsubsection{Chemical Composition}

Inductively Coupled Plasma-Mass Spectroscopy (ICP-MS) was used to measure Cs concentrations and Inductively Coupled Plasma-Atomic Emission Spectroscopy (ICP-AES) was 
used to measure all other elemental concentrations as Cs cannot be measured by ICP-AES. A representative amount from each sample was prepared via a sodium peroxide fusion (PF) method for cation measurements - since typical lithium-metaborate fusion (LM) was not sufficient to dissolve the high concentrations of $\mathrm{TiO}_{2}$ and $\mathrm{Cr}_{2} \mathrm{O}_{3}$. Each sample was prepared in duplicate. Prepared samples were analyzed twice for each element of interest by ICP, with the instrumentation being re-calibrated between the duplicate analyses. Glass standards were also intermittently measured to ensure the performance of the ICP-AES instrument over the course of the analyses. The measured cation concentrations were converted to their respective oxide to obtain a wt. \% of each component oxide.

The $\mathrm{Fe}^{2+} / \mathrm{Fe}^{3+}$ and $\mathrm{Fe}^{2+} / \mathrm{Fe}$ (total) ratios were determined from an absorption method using a UVVis spectrometer. Samples were dissolved in a sulfuric-hydrofluoric acid mixture, containing ammonium vanadate to preserve the $\mathrm{Fe}^{2+}$ content. Boric acid was added to destroy iron-fluoride complexes and ferrozine was added to form ferrous-ferrozine complexes for the determination of $\mathrm{Fe}^{2+}$ content. An additional measurement with ascorbic acid addition to reduce $\mathrm{Fe}^{3+}$ to $\mathrm{Fe}^{2+}$ with a second absorbance measurement was used to determine total Fe [16].

\subsection{Results and Discussion}

\subsection{Processing}

In general, the compositions targeting a Cr-hollandite major phase reacted (solid-state) but exhibited minimal bulk melting. Instead, these samples resembled consolidated powder compacts that were easily removed from the crucible by hand. The compositions targeting a $\mathrm{Cr} / \mathrm{Al} / \mathrm{Fe}$-hollandite major phase exhibited melting and crystallization as evidenced by visible signs of flowing and adhesion to the crucible. Although high purity (99.99\%) alumina crucibles 
were considered suitable for the melt processing studies in this work, the $\mathrm{Cr} / \mathrm{Al} / \mathrm{Fe}$ compositions reacted with the alumina crucibles. Other refractory crucibles would likely react as well, perhaps to a greater extent depending on the material, and it was not desirable to use precious metal crucibles that alloy under reducing conditions. Furthermore, although the effect of alumina impurity on phase formation and processing in the studied compositions was not an objective of this research, aluminum is a reprocessing contaminant, and the results indicate that alumina impurity from the crucible was not detrimental to bulk phase formation.

\subsection{Chemical Composition}

Calculated oxide compositions based on measured elemental concentrations are summarized in Table 5. Standard oxidation states for elements except Fe were assumed in all samples. $\mathrm{Fe}^{2+}$ and $\mathrm{Fe}^{3+}$ concentrations were determined from redox measurements for the $\mathrm{Cr} / \mathrm{Al} / \mathrm{Fe}$ samples. $\mathrm{Fe}^{2+}$ / Fe total fractions are listed in Table 6 for the $\mathrm{Cr} / \mathrm{Al} / \mathrm{Fe}$ samples and were assumed to be the same in the $\mathrm{Cr}$ samples for calculations. The Fe redox measurements confirmed the amount of $\mathrm{Fe}^{2+}$ increased with increasing reduction potential during processing. Target concentrations for samples to which $\mathrm{Ti} / \mathrm{TiO}_{2}$ was added assumed all $\mathrm{Ti}$ reacted to form $\mathrm{TiO}_{2}$. In actuality, several $\mathrm{Ti}$ valence states are expected. The measured compositions were in good agreement with the target (nominal) compositions with the exception of excess $\mathrm{Al}$ and low $\mathrm{Cs}$ concentrations in all samples. Approximately $2 \mathrm{x}-5 \mathrm{x}$ excess $\mathrm{Al}$ was measured than targeted and was attributed to reactions with the $\mathrm{Al}_{2} \mathrm{O}_{3}$ crucibles as noted previously. Approximately $50-90$ wt. \% of the targeted Cs was retained. The low Cs concentration was attributed to the high volatility of Cs at the processing temperatures and is in agreement with previous work [17].

In the $\mathrm{Cr} / \mathrm{Al} / \mathrm{Fe}$ samples, excess $\mathrm{Al}$ was measured in increasing concentrations as follows:

air $\rightarrow$ air w/ $\mathrm{Ti} / \mathrm{TiO}_{2} \rightarrow 1 \% \mathrm{H}_{2} \rightarrow 1 \% \mathrm{H}_{2}$ w/ Ti/TiO 2 . The increasing Al concentration with increasing 
$\mathrm{Fe}^{2+}$ concentration indicates the crucible was a source of $\mathrm{Al}_{2} \mathrm{O}_{3}$ impurity and that the reactions with the crucible were competing with hollandite formation. This result can be deduced from $\mathrm{FeO}-\mathrm{Al}_{2} \mathrm{O}_{3}$ phase diagrams and is supported by XRD data presented in the following section.

Part of this work was intended to evaluate melt processing as a suitable method for incorporating Cs in a hollandite host. Processing in air with Ti additions appears to increase Cs retention compared to the other processing conditions in this study as seen in Table 5. An explanation for this result is that air environments produced fewer varieties of $(2+/ 3+)$ titanate phases that compete for the Cs compared to the $1 \% \mathrm{H}_{2}$ reducing environments, while at the same time $\mathrm{Ti}$ additions that also affect (reduce) the local $\mathrm{Fe}$ and $\mathrm{Ti}$ valence primarily stabilize the hollandite tunnel structure, which promote Cs incorporation in the hollandite phase $[9,10]$. Both these effects in concert seemingly increase the Cs incorporation leaving less Cs available for volatilization.

Although Cs retention was not ideal in samples it is important to note that the low Cs concentrations measured in the as-processed samples does not preclude melt processing as a viable method for several reasons; Cs volatility occurs during other processing routes and the surface to volume ratio of the samples at the laboratory scale enhances volatilization effects compared to what would be expected in a practical process in which much larger volumes would be processed. Furthermore, typical large scale melt processes employ a cold-cap (not practical in this research) that also enhances volatile species retention.

\subsection{X-ray Diffraction}

Quantitative analysis was not performed because of the complexity of the XRD patterns. The terms perovskite and pyrochlore used in this context describe the more general $\mathrm{ATiO}_{3}$ and 
$\mathrm{A}_{2} \mathrm{~B}_{2} \mathrm{O}_{6} / \mathrm{A}_{2} \mathrm{~B}_{2} \mathrm{O}_{7}$ (where A and $\mathrm{B}$ are rare-earth and transition metal cations) type compounds, respectively. The structures of those compounds are highly substitutional, can accommodate multiple cation species on lattice sites, and depend on the cation species and concentration in the compound. All of these factors add complexity to the XRD pattern, and indeed many possible $2+/ 3+$ titanate (pyrochlore/perovskite) phases could be identified in the XRD patterns. For the purposes of this exploratory study, XRD was used only as a gross assessment of the phases. Detailed structure refinements are needed to fully assess the waste-form which, are outside the scope of this work, but will be pursued in subsequent research and communicated in due courses.

XRD confirmed that the samples were, in general, multiphase assemblages of the target phases. The XRD patterns and the identified phases from those patterns are shown in Figure 1. Table 7 summarizes phases identified in the XRD patterns after melt processing. Comparison of the XRD patterns indicates noticeable differences between samples processed in air to those processed in $1 \% \mathrm{H}_{2}$. The XRD patterns for the Cr samples processed in $1 \% \mathrm{H}_{2}$ exhibited one distinct peak at $\sim 32^{\circ} 2 \theta$ whereas the XRD patterns for the $\mathrm{Cr}$ samples processed in air exhibited three distinct peaks between $\sim 25^{\circ}$ and $35^{\circ} 2 \theta$. In all cases those peaks were unidentified, but the peak present in the pattern from the samples processed in $1 \% \mathrm{H}_{2}$ partially match a $\mathrm{Sr}_{3} \mathrm{Mo}_{2} \mathrm{O}_{7}$ (pdf 00-052-1252) double layered perovskite phase and the peaks present in the pattern from samples processed in air partially match $\mathrm{Al}_{2} \mathrm{O}_{3}$ (pdf 00-046-1212) and a $\mathrm{Ba}_{7} \mathrm{Al}_{2} \mathrm{O}_{10}$ (pdf 00-0410164) compound. These results suggest that Mo enters a perovkite phase under reducing conditions, which would support previous evidence that reducing conditions suppress Cs-Mo containing phases. Mo containing perovskites are known to exist and furthermore, recent research on the irradiation of the $\mathrm{Sr}_{2} \mathrm{Fe}_{1.5} \mathrm{Mo}_{0.5} \mathrm{O}_{6-\delta}$ perovskite compound indicated that Mo containing perovskites could be potential waste form materials [18]. This suggests that 
processing in $1 \% \mathrm{H}_{2}$ suppresses Cs-Mo containing phases and promotes Mo partitioning to a durable phase.

The appearance of $\mathrm{Ba}-\mathrm{Al}-\mathrm{O}$ compounds under air environments indicates that at least a portion of the $\mathrm{Ba}$ does not form the targeted phases (pyrochlore and perovskite) with rare earth and transition metal cations, but instead reacts with $\mathrm{Al}_{2} \mathrm{O}_{3}$. However, the presence of excess $\mathrm{Al}_{2} \mathrm{O}_{3}$ itself would suggest that its reaction with $\mathrm{Ba}$ was limited, perhaps due to the high temperature stability of the Cr hollandite phase.

The XRD patterns for the $\mathrm{Cr} / \mathrm{Al} / \mathrm{Fe}$ samples processed in $1 \% \mathrm{H}_{2}$ are more complex (contain more peaks) compared to those same compositions processed in air. Partial pattern matches for those unidentified peaks indicated titanate-based compounds in addition to pyrochlore or perovskite type materials were formed in reducing conditions suggesting that reducing conditions favor parasitic phases at the expense of the desired target phases. In particular, Fe is easily reduced, and because the hollandite phase is sensitive to minor stoichiometric changes, the relative Redox equilibrium for $\mathrm{Fe}$ and $\mathrm{O}$ disrupts the hollandite phase as other, preferred $\mathrm{Fe}$ phases are formed. Indeed, $\mathrm{FeO}$ as well as $\mathrm{BaFe}_{12} \mathrm{O}_{19}$ were identified as likely phases in the $\mathrm{Cr} / \mathrm{Al} / \mathrm{Fe}$ samples processed in $1 \% \mathrm{H}_{2}$. Furthermore, similar effects of reducing atmosphere were not observed to the same extent or type in the $\mathrm{Cr}$ samples as in the $\mathrm{Cr} / \mathrm{Al} / \mathrm{Fe}$ samples.

Taken together, the XRD results indicate that reducing conditions significantly affect the resulting phase assemblages during melt processing. It is known that titanium oxygen equilibrium reactions impact the hollandite stoichiometry in sintered SYNROC materials [10]. In this work, adjustments to the $\mathrm{Ti}^{3+} / \mathrm{Ti}^{4+}$ ratio made by adding $\mathrm{Ti}$ metal to control the hollandite stoichiometry resulted in greater Cs retention (Table 5) as expected based on previous research. 
$\mathrm{Fe}_{2} \mathrm{O}_{3}$ is also relatively easily reduced and impacted phase assemblage during melt processing. Under reducing conditions $\mathrm{Fe}$ species reacted with the crucible and other primary phase constituents as evidenced by the resulting amount of excess $\mathrm{Al}$ and parasitic Fe-containing phases.

\subsection{Electron Microscopy}

Representative back scattered detector (BSD) SEM images of each sample after melt processing are presented in Figure 2. Similar phases were identified in all samples. General assessments of the phases can be made for the images provided in Figure 2. The most abundant mid tone gray corresponds to hollandite phase and the lighter tone gray phase that is also relatively abundant corresponds to pyrochlore and perovskite phases. The darker phases correspond to pores and other minor phases including $\mathrm{TiO}_{2}$ and $\mathrm{Al}_{2} \mathrm{O}_{3}$. More specific phases are identified and labeled in Figure 3 for the samples processed in $1 \% \mathrm{H}_{2}$ with $\mathrm{Ti}^{-} \mathrm{TiO}_{2}$ additions. The microstructures presented in Figure 3 are higher magnification images representative of the melt processing process. Overall, the observed microstructures confirm the XRD results as evidenced by characteristic contrast in the images taken using the BSD mode and semi-quantitative EDS. Excess $\mathrm{Al}_{2} \mathrm{O}_{3}$ and $\mathrm{TiO}_{2}$ were also identified in the $\mathrm{Cr} / \mathrm{Al} / \mathrm{Fe}$ and $\mathrm{Cr}$ samples respectively, in agreement with the XRD results and processing conditions. The morphology between the $\mathrm{Cr}$ and $\mathrm{Cr} / \mathrm{Al} / \mathrm{Fe}$ samples was also different. The $\mathrm{Cr}$ samples exhibited relatively small but dispersed phases whereas the $\mathrm{Cr} / \mathrm{Al} / \mathrm{Fe}$ samples exhibited larger but less dispersed phases in agreement with the processing observations and the high refractory nature of the Cr sample.

The $\mathrm{Cr} / \mathrm{Al} / \mathrm{Fe}$ samples processed with $\mathrm{Ti}-\mathrm{TiO}_{2}$ were further examined using STEM-EDS to identify minor phases not observed in XRD or SEM and to probe elemental partitioning within the various phases. Figure 4 and Figure 5 show select elemental maps taken for the $\mathrm{Cr} / \mathrm{Al} / \mathrm{Fe}$ 
samples processed in air and $1 \% \mathrm{H}_{2}$, respectively, with $\mathrm{Ti}^{-\mathrm{TiO}_{2}}$ additions. Distinct phases are evident in the EDS maps in Figure 4 and Figure 5 and some elements appeared to partition more so than others. In those maps, $\mathrm{Cr}$ is primarily associated with the hollandite phase, as would be expected from previous work and XRD results that indicated the high stability of the Crhollandite analog [9]. $\mathrm{Zr}$ appeared to be associated with $\mathrm{Ca}$ and $\mathrm{Nd}$. Ca likely is associated with a zirconolite phase and a $\left(\mathrm{A}^{3+}\right)_{0.4} \mathrm{Ca}_{0.4} \mathrm{TiO}_{3}$ perovskite, both of which were identified in the XRD patterns. $\mathrm{Nd}$ may also be associated with $\mathrm{Nd}_{2} \mathrm{Zr}_{2} \mathrm{O}_{7}$ phase, a pyrochlore similar to $\mathrm{Y}_{2} \mathrm{Ti}_{2} \mathrm{O}_{7}$ identified in the XRD patterns. Evidence of a $\mathrm{Nd}_{2} \mathrm{Zr}_{2} \mathrm{O}_{7}$ phase indicates that $\mathrm{Zr}$ - rare-earth pyrochlore is viable host for those waste elements without the needed $\mathrm{Ca}$ additions to form zirconolite.

$\mathrm{Fe}$ appeared to be concentrated at the hollandite grain boundaries (compare $\mathrm{Cr}$ and $\mathrm{Fe}$ maps) in the $\mathrm{Cr} / \mathrm{Al} / \mathrm{Fe}$ sample processed in $1 \% \mathrm{H}_{2}$ supporting the $\mathrm{XRD}$ data and in agreement with previous single-phase hollandite results [9]. Fe, thought to be one of the more reactive and mobile species in the composition, was generally confined to the hollandite phase (compare $\mathrm{Cr}$ and Fe maps) in the sample heated in air, but exhibited noticeable concentration gradients. Similar concentration gradients were observed for $\mathrm{Al}$ and $\mathrm{Cs}$, both which are components of the hollandite phase, but not in the other mapped elements, which further indicates the relative instability of the $\mathrm{Cr} / \mathrm{Al} / \mathrm{Fe}$ hollandite phase.

A major difference between the two collections of maps is the distribution of Cs and Mo. As already indicated, Cs does not readily partition exclusively to the $\mathrm{Cr} / \mathrm{Al} / \mathrm{Fe}$ hollandite phase, but reducing atmosphere is known to suppress parasitic phase formation, specifically $\mathrm{Cs}_{2} \mathrm{MoO}_{4}$. Although the Mo and Cs appeared to be distributed throughout each sample there was noticeable Cs-Mo containing phases in the sample heated in air that was not observed in the sample heated 
in $1 \% \mathrm{H}_{2}$. This indicates that reducing atmosphere is effective in reducing (if not eliminating) CsMo containing phases. The relative abundance of Mo in the samples was insufficient to react with all the Cs (assuming $\mathrm{Cs}_{2} \mathrm{MoO}_{4}$ ), according to the sample composition (see Table 5). Cs was also observed in the hollandite phase (see Figure 4) but, it is unknown to what extent Cs reacts to form $\mathrm{Cs}_{2} \mathrm{MoO}_{4}$ versus hollandite. If Mo is the limiting constituent driving Cs reactions, compositions with greater Mo concentrations would be expected to form more $\mathrm{Cs}_{2} \mathrm{MoO}_{4}$ and Csdeficient hollandite. Overall, $\mathrm{La}$ and $\mathrm{Ce}$ (not shown) appeared distributed throughout the pyrochlore and perovskite phases.

In general, melt processing produced large-grain microstructures exhibiting compositional variety within individual phases. In contrast, smaller grains with less compositional inhomogeneity was observed in prior work utilizing sintering techniques [19]. The microstructures that developed during melt processing confirm that relatively rapid mass transport occurred which indicates crystal growth from a melt, compared to sintering processes. In this case, the melt is a solution (contains elements in addition to those in the crystal) and as crystallization progressed, it is speculated that compositional substitution (variety) developed in the growing phase considering that the target titanate phases are known to be substitutional hosts capable of accommodating multiple cations. It is possible that alternative selective crystallization phenomena take place during melt processing that lead to compositional variety. Nevertheless, the melt processed microstructures presented are significantly different than sintered microstructures and further characterization is needed to understand phase evolution and assemblage during melt processing. Additionally, the large grain size in melt processed ceramics could have significant impact on radiation damage and product performance, which also needs to be evaluated. 


\subsection{Conclusions}

This work explored the feasibility of melt processing multiphase ceramics targeting an assemblage of titanate-based phases including hollandites of the form $\mathrm{Ba}_{1.0} \mathrm{Cs}_{0.33} \mathrm{~A}_{2.3} \mathrm{Ti}_{5.7} \mathrm{O}_{16} ; \mathrm{A}=$ $\mathrm{Cr}, \mathrm{Fe}, \mathrm{Al}$. XRD and SEM results indicated that the melt processing method produces similar phases obtained by alternative processing methods, namely zirconolite, perovskite, and pyrochlore structures. The results indicated highly substituted pyrochlore and perovskite phases incorporating multiple lanthanides and transition metals. Processing in reducing atmosphere appeared to reduce un-desirable Cs-Mo containing phases, but at the same time promoted the formation of parasitic phases at the expense of the target hollandite, pyrochlore, and perovskite phases. This research supports previous research demonstrating that $\mathrm{Cr}$ preferentially enters the hollandite phase (even in the presence of competing phases). Due to its refractory nature, $\mathrm{Cr}$ does not form compounds readily with $\mathrm{Cs}$ and $\mathrm{Cr}^{3+}$ is not easily susceptible to reduction. $\mathrm{Cr}_{2} \mathrm{O}_{3}$ appears to stabilize the hollandite phase which in turn promotes Cs incorporation.

\section{Acknowledgements}

This document was prepared in conjunction with work accomplished under Contract No. DEAC09-08SR22470 with the U.S. Department of Energy. TEM was carried out at the Center for Functional Nanomaterials, Brookhaven National Laboratory, which is supported by the U.S. Department of Energy, Office of Basic Energy Sciences, under contract no. DE-AC0298CH10886. The authors acknowledge gratefully the financial support of the DOE-NE Materials Recovery and Waste Form Development program including program support from James Bresee, Kimberly Gray, Terry Todd and John Vienna. David Missimer is acknowledged gratefully for processing and characterization work. 


\section{Table Captions}

Table 1. Projected and re-normalized waste composition targeted in this study.

Table 2. Additive and waste concentrations (wt. \% )used in this study.

Table 3. Target composition of multiphase melt samples; weight percent of oxide component. Table 4 Experimental matrix and processing conditions.

Table 5. Elemental concentrations (note, compositions are not renormalized for $\mathrm{Ti} / \mathrm{TiO}_{2}$ additions).

Table 6. $\mathrm{Fe}^{2+} / \mathrm{Fe}$ total concentrations in $\mathrm{Cr} / \mathrm{Al} / \mathrm{Fe}$ samples after processing in various conditions.

Table 7. Phases Identified in Multiphase Ceramics after Processing. 


\section{Figure captions}

Figure 1. XRD patterns for multiphase ceramic compositions processed under varying conditions. The hollandite, perovskite, and pyrochlore phases were primarily identified via one of the three patterns shown. Additional phase were identified and are labeled in individual patterns. $\left.\mathrm{P}^{\prime}\right)$ perovskite-type; $\mathrm{Y}^{\prime}$ ) pyrochlore-type; $\mathrm{R}$ ) $\mathrm{TiO}_{2}-00-021-1276$; $\mathrm{B}$ ) $\mathrm{Ba}_{7} \mathrm{Al}_{2} \mathrm{O}_{10}-00$ 041-0164; F)BaFe $\left.{ }_{12} \mathrm{O}_{19}-00-039-1433 ; \mathrm{I}\right) \mathrm{FeO}-00-046-1312 ;$ A) $\mathrm{Al}_{2} \mathrm{O}_{3}-00-046-1212$; (S) $\mathrm{Sr}_{3} \mathrm{Mo}_{2} \mathrm{O}_{7}-00-052-1252$. Unidentified peaks are labeled " $u$ ".

Figure 2. Digital SEM images of melt processed multi-phase ceramics.

Figure 3. SEM back scattered detector (BSD) digital images taken of each composition processed in $1 \% \mathrm{H}_{2}$ with $\mathrm{Ti}-\mathrm{TiO}_{2}$. Labeled phases: (1) $\mathrm{Al}_{2} \mathrm{O}_{3}$; (2) $\mathrm{FeO}$ (possible); (3) hollandite, (4) Zirconolite, 5) Perovskite/Pyrochlore $\left(\mathrm{A}_{\mathrm{x}}^{+3} \mathrm{~B}^{+2}{ }_{1-\mathrm{x}}\right) \mathrm{TiO}_{3}$, and 6) rutile.

Figure 4. STEM-EDS elemental mapping measurements of $\mathrm{Cr} / \mathrm{Al} / \mathrm{Fe}$ multi-phase composition processed in air with $\mathrm{Ti}_{-} \mathrm{TiO}_{2}$. (All maps are scaled identically: refer to contrast image for scale $\operatorname{bar}(6 \mu \mathrm{m}))$

Figure 5. STEM-EDS elemental mapping measurements of $\mathrm{Cr} / \mathrm{Al} / \mathrm{Fe}$ multi-phase composition processed in $1 \% \mathrm{H}_{2}$ with $\mathrm{Ti}^{-} \mathrm{TiO}_{2}$. (All maps are scaled identically: refer to contrast image for scale bar $(10 \mu \mathrm{m}))$ 


\section{References}

[1] J.V. Crum, L. Turo, B. Riley, M. Tang, A. Kossoy, J. Am. Ceram. Soc., 95 (2012) 12971303.

[2] J.D. Vienna, Int. J. Appl. Glass Sci., 1 (2010) 309-321.

[3] C. Biagioni, P. Orlandi, M. Pasero, Periodico Di Mineralogia, 78 (2009) 3-11.

[4] A.E. Ringwood, S.E. Kesson, N.G. Ware, W. Hibberson, A. Major, Nature, 278 (1979) 219223.

[5] A.E. Ringwood, S.E. Kesson, N.G. Ware, W.O. Hibberson, A. Major, Geochem. J., 13 (1979) 141-165.

[6] T. Advocat, G. Leturcq, J. Lacombe, G. Berger, R.A. Day, K. Hart, E. Vernaz, A. Bonnetier, Mater. Res. Soc. Symp. Proc, 465 (1997) 355-362.

[7] I.A. Sobolev, S.V. Stefanovskii, B.I. Omelianenko, S.V. Ioudintsev, E.R. Vance, A. Jostons, Mater. Res. Soc. Symp. Proc, 465 (1997) 371-378.

[8] V. Aubin-Chevaldonnet, D. Caurant, A. Dannoux, D. Gourier, T. Charpentier, L. Mazerolles, T. Advocat, J. Nucl. Mater., 366 (2007) 137-160.

[9] J. Amoroso, J. Marra, S.D. Conradson, M. Tang, K. Brinkman, J. Alloys Compd., 584 (2014) 590-599.

[10] S.E. Kesson, Radioactive Waste Manag. Environ. Restor., 4 (1983) 53-72.

[11] D.S.D. Gunn, N.L. Allan, H. Foxhall, J.H. Harding, J.A. Purton, W. Smith, M.J. Stein, I.T. Todorov, K.P. Travis, J. Mater. Chem., 22 (2012) 4675-4680.

[12] R. Ubic, I.M. Reaney, W.E. Lee, J. Mater. Res., 14 (1999) 1576-1580.

[13] H.F. Xu, Y.F. Wang, J. Nucl. Mater., 279 (2000) 100-106.

[14] M.L. Carter, E.R. Vance, H. Li, Mat. Res. Soc. Symp. Proc., 807 (2003) 249-254.

[15] M.L. Carter, E.R. Vance, D.R.G. Mitchell, Z. Zhang, Mat. Res. Soc. Symp. Proc., 824 (2004) CC4.6.1 - 6.

[16] E.W. Baumann; DPST-87-304; Savannah River Laboratory: Aiken, 1987.

[17] K. Brinkman, K. Fox, M. Tang; SRNL-STI-2011-00516 (FCRD-SWF-2011-000310, 2011);

Savannah River National Laboratory: Aiken, SC, 2011.

[18] S. Wang, M. Tang, L. Zhang, G. Xiao, K. Brinkman, F. Chen, J. Alloys Compd., 578 (2013) 170-175.

[19] K. Brinkman, J. Amoroso, J. Marra, M. Tang; SRNL-STI-2013-00442, (FCRD-SWF-2013000229); Savannah River National Laboratory: Aiken, SC, 2013. 
Table 1.

\begin{tabular}{llll}
\hline \hline Group & Fuel $^{\mathrm{a}}$ & $\mathrm{SRNL}^{\mathrm{b}}$ & Fuel $^{\mathrm{c}}$ \\
\hline \hline Alkali & 7.6 & 13.4 & 9.6 \\
Alkaline Earth & 8.3 & 12.9 & 10.6 \\
Lanthanides & 33.1 & 51.8 & 42.0 \\
Actinides & 4.0 & - & - \\
Noble Metals & 14.6 & - & - \\
$\mathrm{MoO}_{3}$ & 13.7 & 3.4 & 17.4 \\
$\mathrm{ZrO}_{2}$ & 13.7 & 12.1 & 17.4 \\
$\mathrm{TcO}_{2}$ & 2.7 & - & - \\
Others & 2.4 & 6.3 & 3.0 \\
\hline Total & 100 & 100 & 100 \\
\hline \hline
\end{tabular}

${ }^{a}$ Projection

${ }^{\mathrm{b}}$ Does not include corrosion and process products

${ }^{c}$ Renormalized to exclude corrosion and process products 
Table 2.

\begin{tabular}{cccc}
\hline \hline Component & Target Phase & CAF-MP & Cr-MP \\
\hline \hline Waste & Various & $\mathbf{2 4 . 6 6}$ & $\mathbf{2 4 . 5 8}$ \\
$\mathrm{Al}_{2} \mathrm{O}_{3}$ & Hollandite & 1.27 & 0 \\
$\mathrm{TiO}_{2}$ & Various & 49.16 & 49.01 \\
$\mathrm{CaO}$ & Zirconolite & 1.39 & 1.38 \\
$\mathrm{BaO}$ & Hollandite & 10.56 & 10.52 \\
$\mathrm{Fe}_{2} \mathrm{O}_{3}$ & Hollandite & 6.65 & 0 \\
$\mathrm{Cr}_{2} \mathrm{O}_{3}$ & Hollandite & 6.33 & 14.5 \\
\hline \hline
\end{tabular}


Table 3.

\begin{tabular}{|c|c|c|c|}
\hline \multirow{2}{*}{ Oxide } & \multicolumn{2}{|c|}{ Target wt. \% } & \multirow[t]{2}{*}{ Target Phase } \\
\hline & CAF-MP & Cr-MP & \\
\hline $\mathrm{Al}_{2} \mathrm{O}_{3}$ & 1.27 & 0.00 & Cs-Hollandite $\left(\mathrm{Ba}_{\mathrm{x}} \mathrm{Cs}_{\mathrm{y}}\right)(\mathrm{Ti}, \mathrm{Al})^{+3}{ }_{2 \mathrm{x}+\mathrm{y}}\left(\mathrm{Ti}^{+4}{ }_{8-2 \mathrm{x}-\mathrm{y}}\right) \mathrm{O}_{16}$ \\
\hline $\mathrm{BaO}$ & 12.76 & 12.72 & Cs-Hollandite $\left(\mathrm{Ba}_{\mathrm{x}} \mathrm{Cs}_{\mathrm{y}}\right)(\mathrm{Ti}, \mathrm{Al})^{+3}{ }_{2 \mathrm{x}+\mathrm{y}}\left(\mathrm{Ti}^{+4}{ }_{8-2 \mathrm{x}-\mathrm{y}}\right) \mathrm{O}_{16}$ \\
\hline $\mathrm{CaO}$ & 1.39 & 1.38 & (4+) Zirconolite $\mathrm{CaZrTi}_{2} \mathrm{O}_{7}$ \\
\hline $\mathrm{Cr}_{2} \mathrm{O}_{3}$ & 6.33 & 14.50 & Cs-Hollandite $\left(\mathrm{Ba}_{\mathrm{x}} \mathrm{Cs}_{\mathrm{y}}\right)(\mathrm{Ti}, \mathrm{Al})^{+3}{ }_{2 \mathrm{x}+\mathrm{y}}\left(\mathrm{Ti}^{+4}{ }_{8-2 x-\mathrm{y}}\right) \mathrm{O}_{16}$ \\
\hline $\mathrm{CdO}$ & 0.11 & 0.11 & - \\
\hline $\mathrm{Ce}_{2} \mathrm{O}_{3}$ & 3.10 & 3.09 & $(2+/ 3+)$ Titanate (i.e. Perovskite / Pyrochlore) $\left(\mathrm{A}^{2+}\right) \mathrm{TiO}_{3} ;\left(\mathrm{A}^{3+}\right)_{2} \mathrm{Ti}_{2} \mathrm{O}_{7}$ \\
\hline $\mathrm{Cs}_{2} \mathrm{O}$ & 2.88 & 2.87 & $(2+/ 3+)$ Titanate (i.e. Perovskite / Pyrochlore) $\left(\mathrm{A}^{2+}\right) \mathrm{TiO}_{3} ;\left(\mathrm{A}^{3+}\right)_{2} \mathrm{Ti}_{2} \mathrm{O}_{7}$ \\
\hline $\mathrm{Eu}_{2} \mathrm{O}_{3}$ & 0.17 & 0.17 & $(2+/ 3+)$ Titanate (i.e. Perovskite / Pyrochlore) $\left(\mathrm{A}^{2+}\right) \mathrm{TiO}_{3} ;\left(\mathrm{A}^{3+}\right)_{2} \mathrm{Ti}_{2} \mathrm{O}_{7}$ \\
\hline $\mathrm{Fe}_{2} \mathrm{O}_{3}$ & 6.65 & 0.00 & Cs-Hollandite $\left(\mathrm{Ba}_{\mathrm{x}} \mathrm{Cs}_{\mathrm{y}}\right)(\mathrm{Ti}, \mathrm{Al})^{+3}{ }_{2 \mathrm{x}+\mathrm{y}}\left(\mathrm{Ti}^{+4}{ }_{8-2 \mathrm{x}-\mathrm{y}}\right) \mathrm{O}_{16}$ \\
\hline $\mathrm{Gd}_{2} \mathrm{O}_{3}$ & 0.16 & 0.16 & $(2+/ 3+)$ Titanate (i.e. Perovskite / Pyrochlore) $\left(\mathrm{A}^{2+}\right) \mathrm{TiO}_{3} ;\left(\mathrm{A}^{3+}\right)_{2} \mathrm{Ti}_{2} \mathrm{O}_{7}$ \\
\hline $\mathrm{La}_{2} \mathrm{O}_{3}$ & 1.58 & 1.58 & $(2+/ 3+)$ Titanate (i.e. Perovskite / Pyrochlore) $\left(\mathrm{A}^{2+}\right) \mathrm{TiO}_{3} ;\left(\mathrm{A}^{3+}\right)_{2} \mathrm{Ti}_{2} \mathrm{O}_{7}$ \\
\hline $\mathrm{MoO}_{3}$ & 0.85 & 0.84 & - \\
\hline $\mathrm{Nd}_{2} \mathrm{O}_{3}$ & 5.23 & 5.22 & $(2+/ 3+)$ Titanate (i.e. Perovskite / Pyrochlore) $\left(\mathrm{A}^{2+}\right) \mathrm{TiO}_{3} ;\left(\mathrm{A}^{3+}\right)_{2} \mathrm{Ti}_{2} \mathrm{O}_{7}$ \\
\hline $\mathrm{Pr}_{2} \mathrm{O}_{3}$ & 1.45 & 1.44 & $(2+/ 3+)$ Titanate (i.e. Perovskite / Pyrochlore) $\left(\mathrm{A}^{2+}\right) \mathrm{TiO}_{3} ;\left(\mathrm{A}^{3+}\right)_{2} \mathrm{Ti}_{2} \mathrm{O}_{7}$ \\
\hline $\mathrm{Rb}_{2} \mathrm{O}$ & 0.42 & 0.42 & Cs-Hollandite $\left(\mathrm{Ba}_{\mathrm{x}} \mathrm{Cs}_{\mathrm{y}}\right)(\mathrm{Ti}, \mathrm{Al})^{+3}{ }_{2 \mathrm{x}+\mathrm{y}}\left(\mathrm{Ti}^{+4}{ }_{8-2 \mathrm{x}-\mathrm{y}}\right) \mathrm{O}_{16}$ \\
\hline $\mathrm{SeO}_{2}$ & 0.08 & 0.08 & - \\
\hline $\mathrm{Sm}_{2} \mathrm{O}_{3}$ & 1.08 & 1.07 & $(2+/ 3+)$ Titanate (i.e. Perovskite / Pyrochlore) $\left(\mathrm{A}^{2+}\right) \mathrm{TiO}_{3} ;\left(\mathrm{A}^{3+}\right)_{2} \mathrm{Ti}_{2} \mathrm{O}_{7}$ \\
\hline $\mathrm{SnO}_{2}$ & 0.07 & 0.07 & (4+) Zirconolite $\mathrm{CaZrTi}_{2} \mathrm{O}_{7}$ \\
\hline $\mathrm{SrO}$ & 0.98 & 0.98 & $(2+/ 3+)$ Titanate (i.e. Perovskite / Pyrochlore) $\left(\mathrm{A}^{2+}\right) \mathrm{TiO}_{3} ;\left(\mathrm{A}^{3+}\right)_{2} \mathrm{Ti}_{2} \mathrm{O}_{7}$ \\
\hline $\mathrm{TeO}_{2}$ & 0.66 & 0.65 & - \\
\hline $\mathrm{TiO}_{2}$ & 49.16 & 49.01 & Various \\
\hline $\mathrm{Y}_{2} \mathrm{O}_{3}$ & 0.63 & 0.63 & $(2+/ 3+)$ Titanate (i.e. Perovskite / Pyrochlore) $\left(\mathrm{A}^{2+}\right) \mathrm{TiO}_{3} ;\left(\mathrm{A}^{3+}\right)_{2} \mathrm{Ti}_{2} \mathrm{O}_{7}$ \\
\hline $\mathrm{ZrO}_{2}$ & 2.99 & 2.98 & (4+) Zirconolite $\mathrm{CaZrTi}_{2} \mathrm{O}_{7}$ \\
\hline
\end{tabular}


Table 4.

\begin{tabular}{cccc}
\hline \hline Composition ID & TiO $_{2}$ Buffer & Atmosphere & Sample-ID \\
\hline \hline \multirow{3}{*}{ Cr-MP } & \multirow{2}{*}{ No } & Air & Cr-MP \\
& & $1 \% \mathrm{H}_{2}$ & Cr-MP-R \\
& Yes & Air & Cr-MP-Ti \\
& & $1 \% \mathrm{H}_{2}$ & Cr-MP-R-Ti \\
& \multirow{2}{*}{ No } & Air & CAF-MP \\
& & $1 \% \mathrm{H}_{2}$ & CAF-MP-R \\
& Yes & Air & CAF-MP-Ti \\
& & $1 \% \mathrm{H}_{2}$ & CAF-MP-R-Ti \\
\hline \hline
\end{tabular}

a "Cr- ..." targeted $\mathrm{Ba}_{1.0} \mathrm{Cs}_{0.3} \mathrm{Cr}_{2.3} \mathrm{Ti}_{5.7} \mathrm{O}_{16}$ Hollandite; "CAF-..." targeted $\mathrm{Ba}_{1.0} \mathrm{Cs}_{0.3} \mathbf{C r}_{1.0} \mathbf{A l}_{0.3} \mathbf{F e}_{1.0} \mathrm{Ti}_{5.7} \mathrm{O}_{16}$ Hollandite. 
Table 5.

\begin{tabular}{|c|c|c|c|c|c|c|c|c|c|c|c|c|}
\hline \multirow[b]{2}{*}{ Oxide } & \multicolumn{6}{|c|}{ Cr-MP Processing Conditions } & \multicolumn{6}{|c|}{ CAF-MP Processing Conditions } \\
\hline & $\begin{array}{l}\text { Target } \\
\text { (g) }\end{array}$ & Air & $1 \% \mathrm{H}_{2}$ & $\begin{array}{c}\text { Target } \\
\text { (g) }\end{array}$ & $\begin{array}{c}\mathrm{Air} \\
\mathrm{w} / \mathrm{Ti}- \\
\mathrm{TiO}_{2} \\
\end{array}$ & $\begin{array}{c}1 \% \mathrm{H}_{2} \\
\mathrm{w} / \mathrm{Ti}- \\
\mathrm{TiO}_{2} \\
\end{array}$ & $\begin{array}{c}\text { Target } \\
\text { (g) }\end{array}$ & Air & $1 \% \mathrm{H}_{2}$ & $\begin{array}{c}\text { Target } \\
\text { (g) }\end{array}$ & $\begin{array}{c}\text { Air } \\
\text { w/Ti- } \\
\mathrm{TiO}_{2} \\
\end{array}$ & $\begin{array}{l}1 \% \mathrm{H}_{2} \\
\mathrm{w} / \mathrm{Ti}- \\
\mathrm{TiO}_{2} \\
\end{array}$ \\
\hline $\mathrm{Al}_{2} \mathbf{O}_{3}$ & $\mathbf{0}$ & 0.28 & 0.34 & 0.00 & 0.35 & 0.43 & 1.27 & 3.57 & 7.25 & 1.15 & 2.37 & 10.4 \\
\hline $\mathrm{BaO}$ & 12.72 & 12.8 & 12.8 & 11.53 & 11.2 & 11.3 & 12.76 & 12.4 & 12.4 & 11.6 & 10.9 & 10.6 \\
\hline $\mathrm{CaO}$ & 1.38 & 1.60 & 1.48 & 1.25 & 1.35 & 1.53 & 1.39 & 1.37 & 1.29 & 1.26 & 1.27 & 0.85 \\
\hline $\mathrm{CdO}$ & 0.11 & 0.00 & 0.00 & 0.10 & 0.00 & 0.00 & 0.11 & 0.00 & 0.00 & 0.10 & 0.00 & 0.00 \\
\hline $\mathrm{Ce}_{2} \mathrm{O}_{3}$ & 3.09 & 3.45 & 3.30 & 2.80 & 3.05 & 3.13 & 3.1 & 3.19 & 3.07 & 2.81 & 2.95 & 2.62 \\
\hline $\mathrm{Cr}_{2} \mathrm{O}_{3}$ & 14.5 & 14.7 & 14.8 & 13.15 & 12.9 & 13.1 & 6.33 & 6.51 & 7.37 & 5.74 & 5.98 & 5.29 \\
\hline $\mathrm{Cs}_{2} \mathrm{O}$ & 2.87 & 1.73 & 1.62 & 2.60 & 2.23 & 1.82 & 2.88 & 1.77 & 1.45 & 2.61 & 2.53 & 1.65 \\
\hline $\mathbf{E u}_{2} \mathbf{O}_{3}$ & 0.17 & 0.19 & 0.18 & 0.15 & 0.17 & 0.17 & 0.17 & 0.17 & 0.17 & 0.15 & 0.16 & 0.15 \\
\hline $\mathrm{Fe}_{2} \mathrm{O}_{3}$ & 0 & 0.06 & 0.00 & 0.00 & 0.11 & 0.00 & 6.65 & 4.75 & 0.00 & 6.03 & 4.19 & 0.00 \\
\hline $\mathrm{FeO}$ & 0 & 0.02 & 0.08 & 0.00 & 0.04 & 0.07 & 0 & 1.52 & 5.23 & 0.00 & 1.41 & 4.70 \\
\hline $\mathbf{G d}_{2} \mathrm{O}_{3}$ & 0.16 & 0.18 & 0.18 & 0.15 & 0.16 & 0.16 & 0.16 & 0.16 & 0.15 & 0.15 & 0.15 & 0.13 \\
\hline $\mathrm{La}_{2} \mathrm{O}_{3}$ & 1.58 & 1.42 & 1.36 & 1.43 & 1.20 & 1.27 & 1.58 & 1.29 & 1.20 & 1.43 & 1.19 & 1.09 \\
\hline $\mathrm{MoO}_{3}$ & 0.84 & 0.24 & 0.30 & 0.76 & 0.53 & 0.30 & 0.85 & 0.36 & 0.32 & 0.77 & 0.61 & 0.26 \\
\hline $\mathrm{Nd}_{2} \mathrm{O}_{3}$ & 5.22 & 5.31 & 5.07 & 4.73 & 4.83 & 5.04 & 5.23 & 4.93 & 4.81 & 4.74 & 4.87 & 4.19 \\
\hline $\mathrm{Pr}_{2} \mathrm{O}_{3}$ & 1.44 & 1.64 & 1.55 & 1.31 & 1.53 & 1.47 & 1.45 & 1.50 & 1.45 & 1.31 & 1.46 & 1.25 \\
\hline $\mathbf{R} \mathbf{b}_{2} \mathbf{O}$ & 0.42 & 0.32 & 0.29 & 0.38 & 0.36 & 0.33 & 0.42 & 0.30 & 0.26 & 0.38 & 0.44 & 0.32 \\
\hline $\mathrm{SeO}_{2}$ & 0.08 & 0.00 & 0.00 & 0.07 & 0.00 & 0.00 & 0.08 & 0.00 & 0.00 & 0.07 & 0.00 & 0.00 \\
\hline $\mathrm{Sm}_{2} \mathrm{O}_{3}$ & 1.07 & 1.13 & 1.10 & 0.97 & 1.02 & 1.05 & 1.08 & 1.05 & 1.01 & 0.98 & 0.99 & 0.80 \\
\hline $\mathrm{SnO}_{2}$ & 0.07 & 0.00 & 0.00 & 0.06 & 0.00 & 0.00 & 0.07 & 0.00 & 0.00 & 0.06 & 0.00 & 0.00 \\
\hline SrO & 0.98 & 1.09 & 1.04 & 0.89 & 0.98 & 0.98 & 0.98 & 0.99 & 0.95 & 0.89 & 0.94 & 0.70 \\
\hline $\mathrm{TeO}_{2}$ & 0.65 & 0.16 & 0.15 & 0.59 & 0.18 & 0.16 & 0.66 & 0.29 & 0.16 & 0.60 & 0.36 & 0.15 \\
\hline $\mathrm{TiO}_{2}$ & 49.01 & 50.1 & 49.3 & 53.80 & 53.8 & 54.1 & 49.16 & 47.8 & 47.1 & 53.9 & 53.7 & 49.0 \\
\hline $\mathbf{Y}_{2} \mathbf{O}_{3}$ & 0.63 & 0.65 & 0.63 & 0.57 & 0.58 & 0.60 & 0.63 & 0.60 & 0.77 & 0.57 & 0.56 & 0.50 \\
\hline $\mathrm{ZrO}_{2}$ & 2.98 & 2.98 & 2.98 & 2.70 & 2.63 & 2.73 & 2.99 & 2.77 & 2.71 & 2.71 & 2.52 & 2.36 \\
\hline Total & 100.0 & 100.1 & 98.5 & 100.0 & 99.2 & 99.7 & 100.0 & 97.3 & 99.1 & 100.0 & 99.5 & 97.0 \\
\hline
\end{tabular}


Table 6.

\begin{tabular}{lcl}
\hline Short Identifier & $\mathbf{F e}^{2+} / \mathbf{F e}$ Total & \multicolumn{1}{c}{$\begin{array}{c}\text { Processing } \\
\text { Conditions }\end{array}$} \\
\hline CAF-MPB1A & 0.263 & Air \\
\hline CAF-MPB1A-Ti & 0.272 & Air w/Ti-TiO 2 \\
\hline CAF-MPB1R & $\mathrm{All} \mathrm{Fe}^{2+}$ & $1 \% \mathrm{H}_{2}$ \\
\hline CAF-MPB1R-Ti & $\mathrm{All} \mathrm{Fe}^{2+}$ & $1 \% \mathrm{H}_{2}$ w/Ti-TiO \\
\hline \hline
\end{tabular}


Table 7.

\begin{tabular}{|c|c|c|c|c|c|}
\hline \multirow[b]{2}{*}{ Short Identifier } & \multicolumn{4}{|c|}{ Phases } & \multirow{2}{*}{$\begin{array}{l}\text { Processing } \\
\text { Conditions }\end{array}$} \\
\hline & $\begin{array}{l}\text { Cs- } \\
\text { Hollandite }\end{array}$ & $\begin{array}{l}(4+) \\
\text { Zirconolite }\end{array}$ & $\begin{array}{l}(2+/ 3+) \\
\text { Titanate }\end{array}$ & Other & \\
\hline Cr-MPB1A & $\mathrm{X}$ & $\mathrm{X}$ & $X$ & $\begin{array}{l}\mathrm{Ba}_{7} \mathrm{Al}_{2} \mathrm{O}_{10} \\
\mathrm{Al}_{2} \mathrm{O}_{3} \\
\mathrm{TiO}_{2}\end{array}$ & Air \\
\hline Cr-MPB1A-Ti & $\mathrm{X}$ & $X$ & $X$ & $\begin{array}{l}\mathrm{Ba}_{7} \mathrm{Al}_{2} \mathrm{O}_{10} \\
\mathrm{Al}_{2} \mathrm{O}_{3} \\
\mathrm{TiO}_{2}\end{array}$ & Air w/Ti-TiO 2 \\
\hline Cr-MPB1R & $\mathrm{X}$ & $X$ & $\mathrm{X}$ & $\mathrm{Sr}_{3} \mathrm{Mo}_{2} \mathrm{O}_{7}$ & $1 \% \mathrm{H}_{2}$ \\
\hline Cr-MPB1R-Ti & $\mathrm{X}$ & $X$ & $X$ & $\begin{array}{l}\mathrm{Sr}_{3} \mathrm{Mo}_{2} \mathrm{O}_{7} \\
\mathrm{TiO}_{2}\end{array}$ & $1 \% \mathrm{H}_{2}$ w/Ti- $\mathrm{TiO}_{2}$ \\
\hline CAF-MPB1A & $\mathrm{X}$ & $\mathrm{X}$ & $\mathrm{X}$ & $\mathrm{Ba}_{7} \mathrm{Al}_{2} \mathrm{O}_{10}$ & Air \\
\hline CAF-MPB1A-Ti & $\mathrm{X}$ & $\mathrm{X}$ & $\mathrm{X}$ & $\begin{array}{l}\mathrm{Ba}_{7} \mathrm{Al}_{2} \mathrm{O}_{10} \\
\mathrm{Al}_{2} \mathrm{O}_{3} \\
\mathrm{TiO}_{2}\end{array}$ & Air w/Ti-TiO 2 \\
\hline CAF-MPB1R & $X$ & $X$ & $X$ & $\begin{array}{l}\mathrm{BaFe}_{12} \mathrm{O}_{19} \\
\text { Unidentified }\end{array}$ & $1 \% \mathrm{H}_{2}$ \\
\hline CAF-MPB1R-Ti & $\mathrm{X}$ & $\mathrm{X}$ & $\mathrm{X}$ & $\begin{array}{l}\mathrm{Ba}_{7} \mathrm{Al}_{2} \mathrm{O}_{10} \\
\mathrm{BaFe}_{12} \mathrm{O}_{19} \\
\mathrm{FeO} \\
\text { Unidentified }\end{array}$ & $1 \% \mathrm{H}_{2} \mathrm{w} / \mathrm{Ti}-\mathrm{TiO}_{2}$ \\
\hline
\end{tabular}


Figure 1.
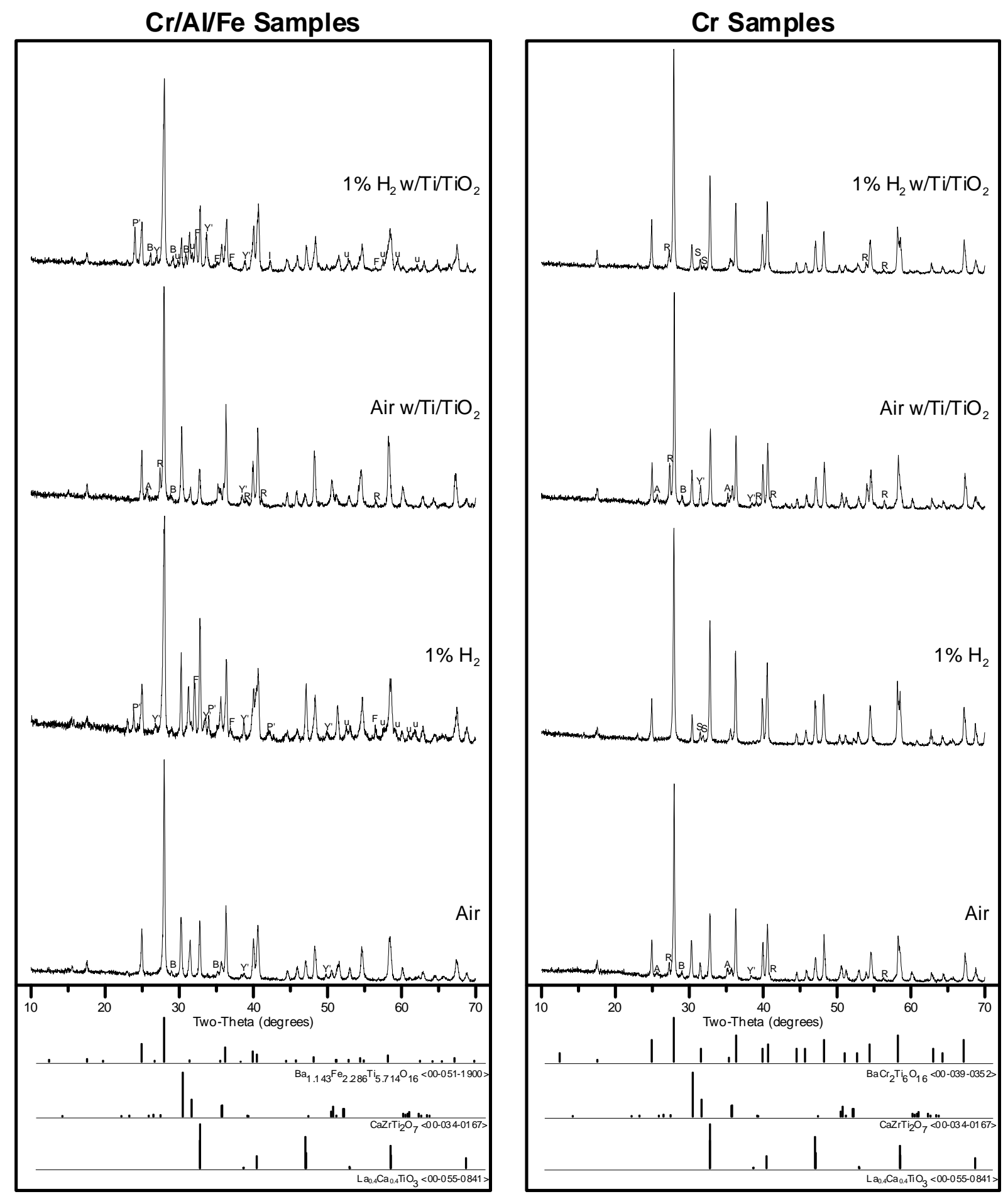
Figure 2.
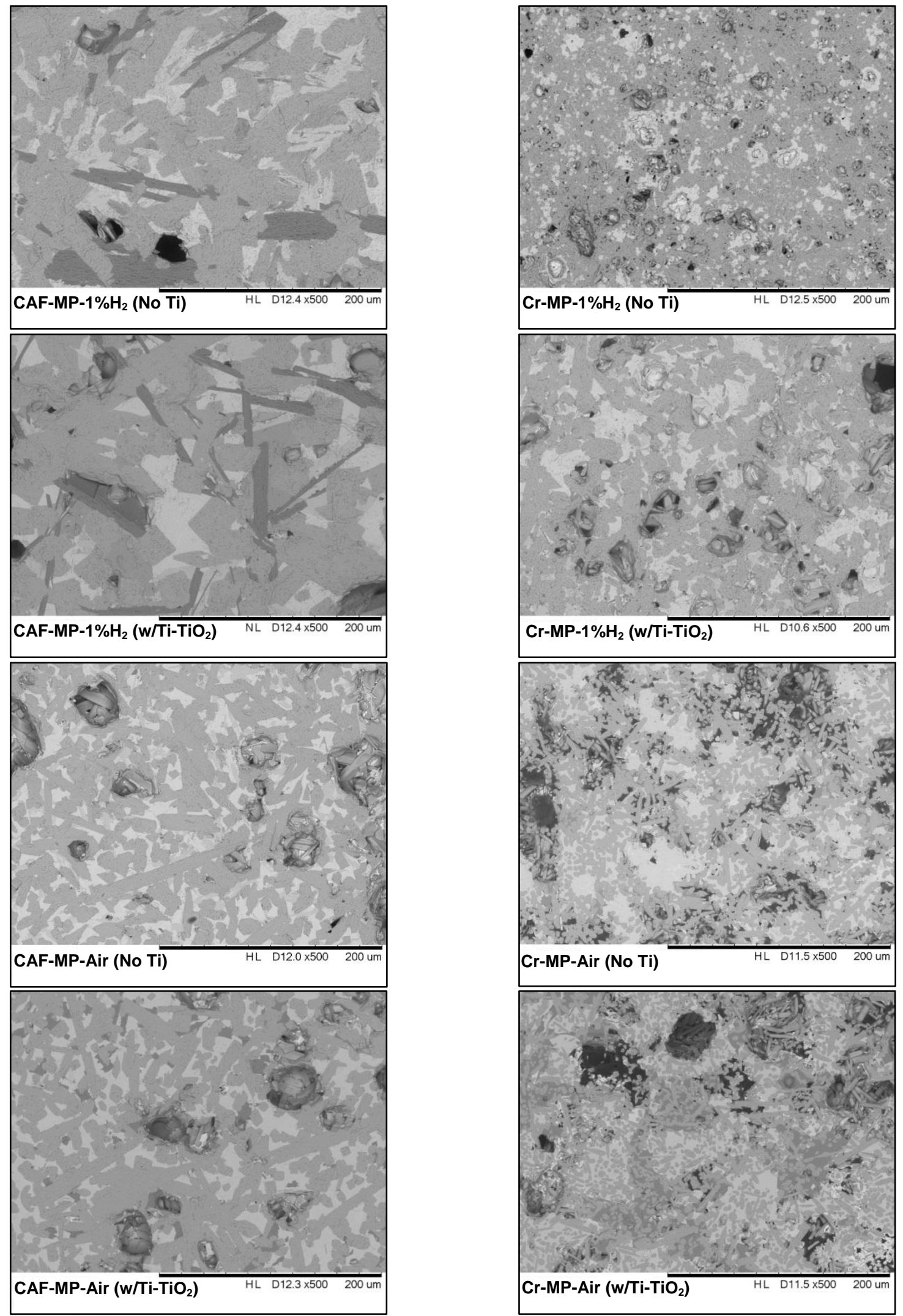
Figure 3.
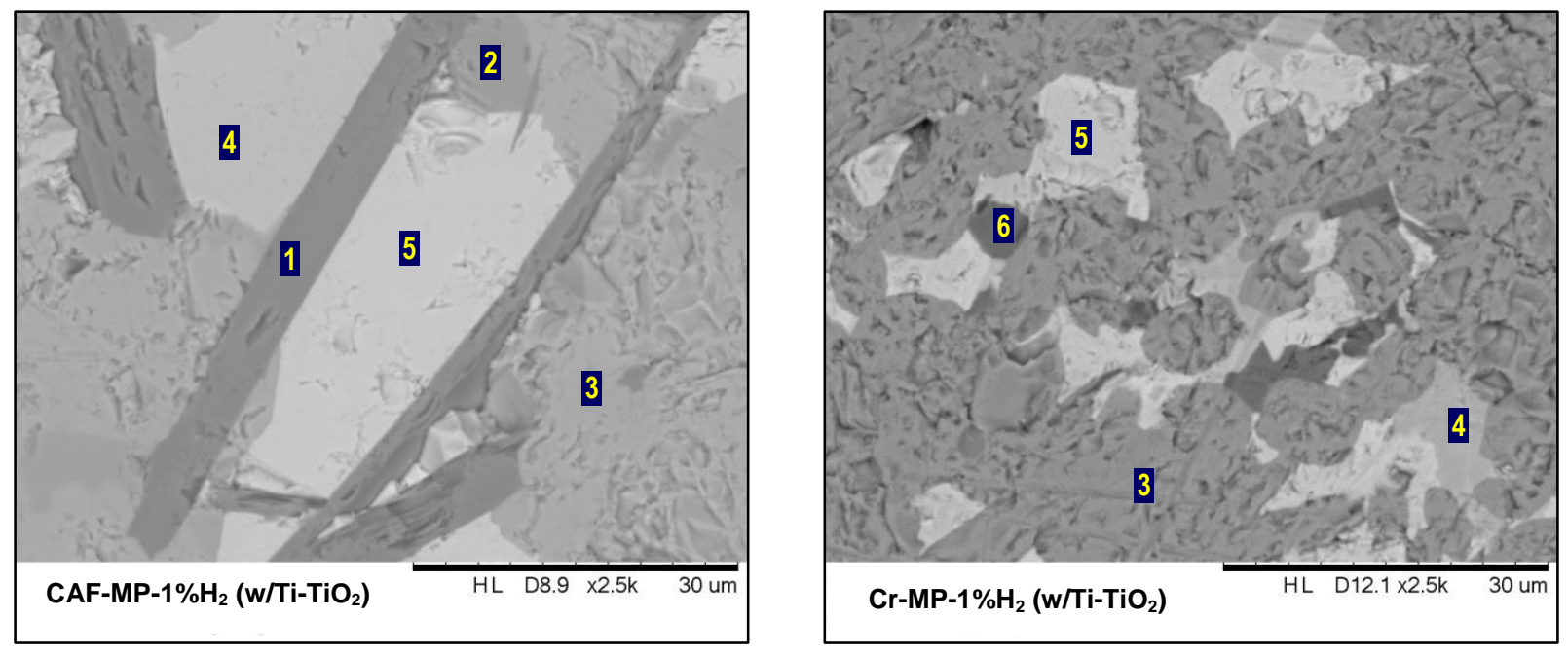
Figure 4.

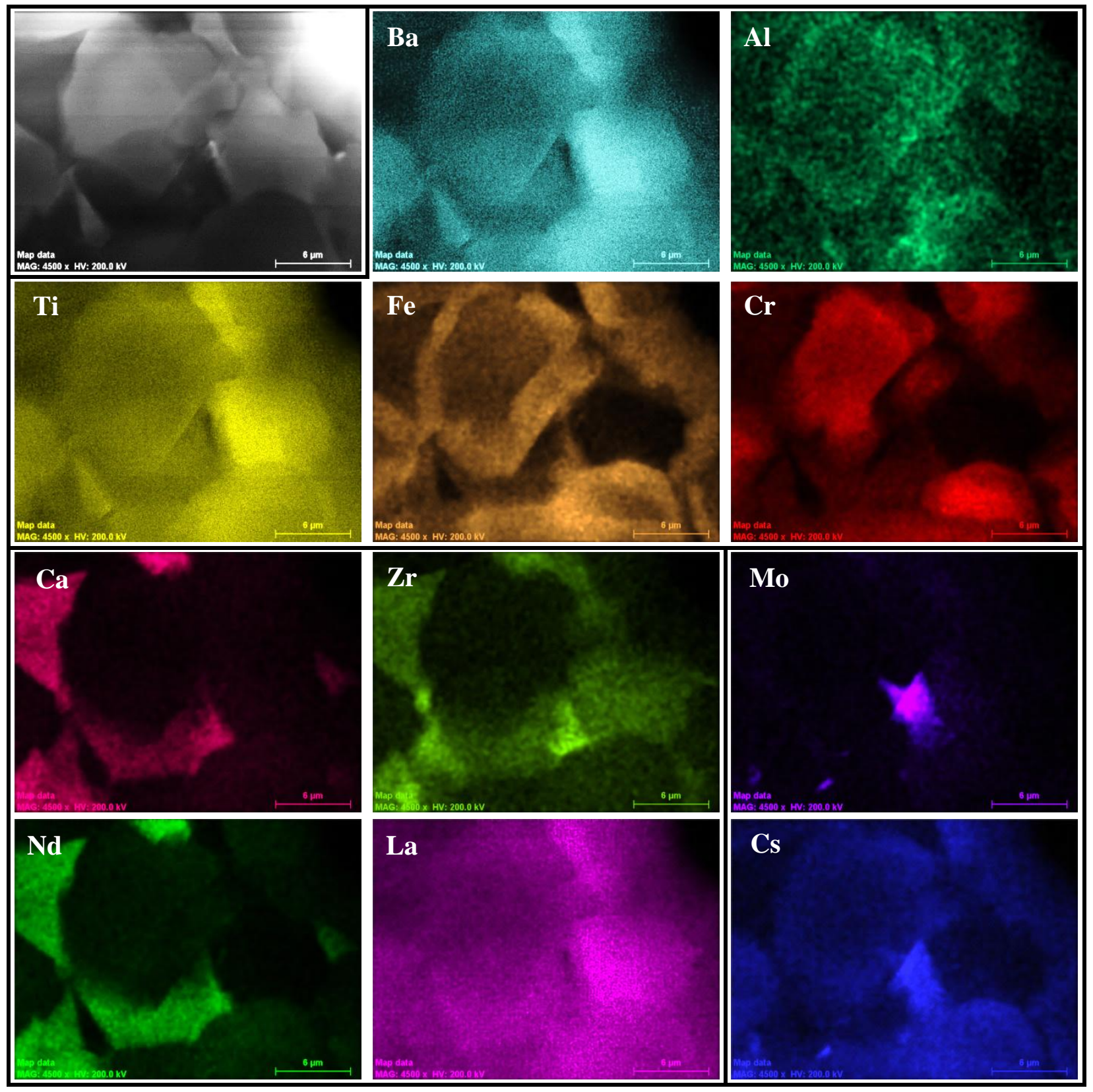


Figure 5.

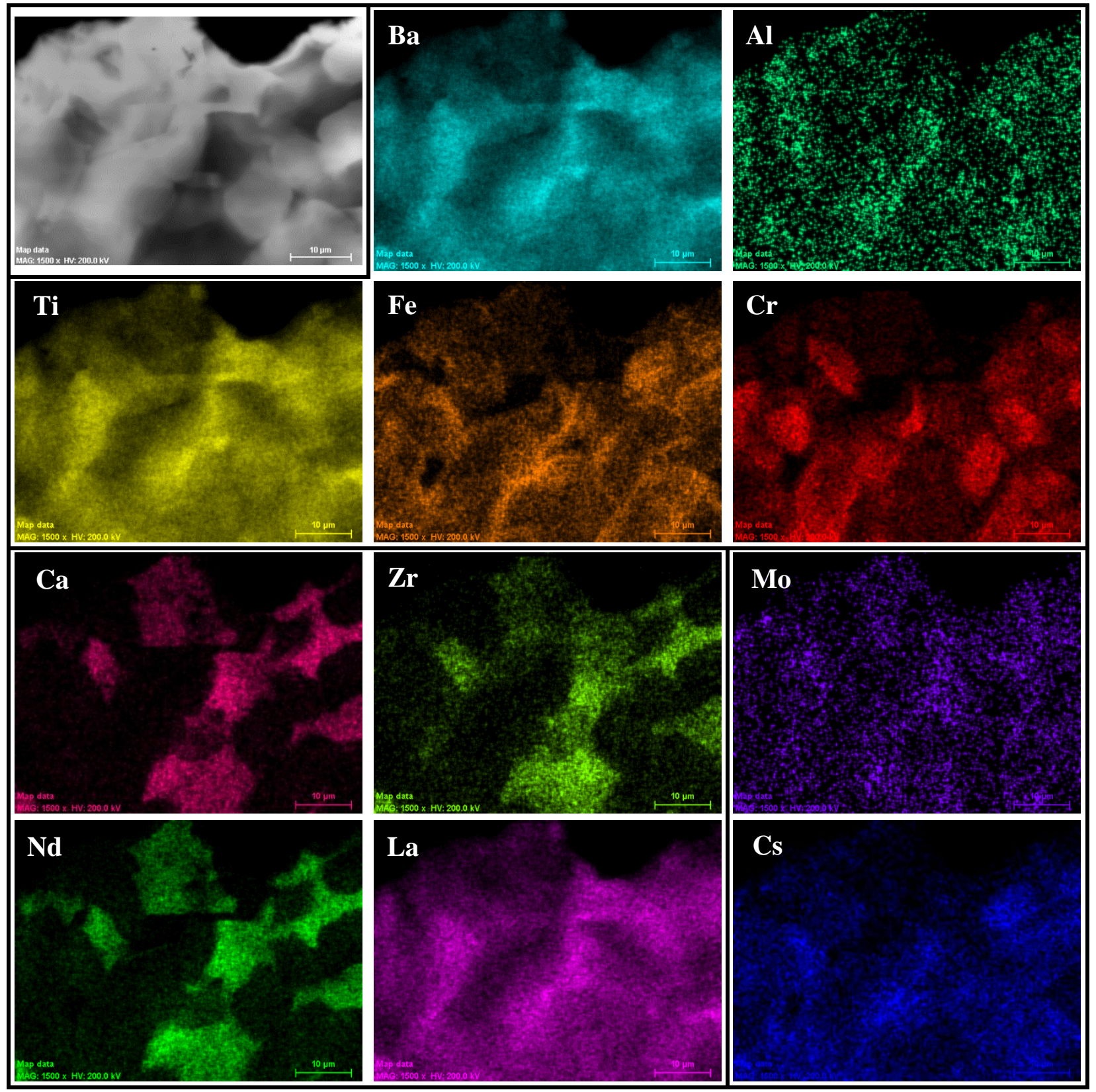

